\title{
Implementasi Metode UCD (User Centered Design) Pada Rancang Bangun Sistem Informasi Perpustakaan (Studi Kasus : SMK Negeri 1 Gelumbang)
}

\author{
Khana Wijaya \\ Program Studi Sistem Informasi, STMIK Prabumulih \\ Khanawijaya90@gmail.com
}

\begin{abstract}
Libraries play an important role in advancing the institute of education because the library is a place to improve knowledge for the students. In the library of SMK Negeri 1 Gelumbang running processes such as member registration, input data on prospective member, borrowing and returning books, book data input and book catalog still written in the ledger. Avoid delays in the system library service SMK Negeri 1 Gelumbang, it is necessary to design an information system library that can help and easier the activities of the circulation of the books. In the information system library SMK Negeri 1 Gelumbang uses (User Centered Design) dan UML (Unified Modeling Language) as well as for language programmer PHP with a MySQL database. Hopefully with this library information system it can solve the problems which exist in the library and can help in the development of science students.
\end{abstract}

Keywords: PHP, libraries, (User Centered Design) dan UML (Unified Modeling Language)

\begin{abstract}
Abstrak
Perpustakaan Berperan penting dalam memajukan lebaga pendidikan karena perpustakaan merupakan tempat untuk meningkatkan ilmu pengetahuan bagi siswa. Pada perpustakaan SMK Negeri 1 Gelumbang proses yang sedang berjalan seperti pendaftaran anggota, penginputan data calon anggota, peminjaman dan pengembalian buku, penginputan data buku dan katalog buku masih ditulis dalam buku besar. Menghindari keterlambatan dalam sistem pelayanan perpustakaan SMK Negeri 1 Gelumbang, maka sangat diperlukan sistem informasi perpustakaan yang dapat membantu dan mempermudah kegiatan sirkulasi buku. Pada sistem informasi perpustakaan SMK Negeri 1 Gelumbang inimenggunakan metode UCD (User Centered Design) dan UML (Unified Modeling Language) serta untuk bahasa pemrograman menggunak PHP dengan database MySQL.
\end{abstract}

Kata kunci: PHP, perpustakaan, UCD (User Centered Design) dan UML (Unified Modeling Language) 


\section{Pendahuluan}

Pendidikan merupakan salah satu pilar untuk menunjang kemajuan suatu bangsa. Proses belajar mengajar menjadi proses yang sangat penting dalam pengembangan dunia pendidikan. Untuk menunjang proses belajar mengajar tersebut memerlukan referensi baca yang baik berupa buku, kamus, majalah, dan sumber bacaan lain [1]. Perrpustakaan merupakan tempat untuk mencari ilmu, menemukan referensi dan menyimpan bahan pustaka yang digunakan oleh manusia untuk mencari informasi. Semakin banyaknya buku dan cepatnya perkembangan ilmu pengetahuan membuat para pembaca mengalami kesulitan dalam pencarian buku. Tidak semua pembaca mempunyai banyak waktu untuk berkunjung ke perpustakaan untuk mencari buku referensi yang dibutuhkan [2].

Perpustakaan SMK Negeri 1 Gelumbang memiliki peralatan dan perlengkapan yang memadai. Serta siswa atau siswi telah diwajibkan menjadi anggota perpustakaan sekolah. Namun proses pelayanan yang dilakukan masih secara konvensional yaitu semua pendataannya masih ditulis dalam buku besar dan saat mencari data buku yang dibutuhkan harus membuka satu per satu halaman buku, hal tersebut menyebabkan lambatnya dalam pencarian data, layanan sirkulasi ataupun pembuatan laporan sistem ini sudah dianggap tidak efisien lag imengingat pesatnya peningkatan jumlah judul dan jumlah buku untuk mengatasi permasalahan tersebut diperlukan suatu sistem informasi. Untuk memenuhi pelayanan yang baik dan efisien terhadap para anggotanya, perpustakaan memerlukan suatu sistem informasi yang dapat membantu para anggota dalam mencari informasi atau referensi tentang data-data yang diperlukan.

Sistem informasi yang harus dilakukan yaitu pendaftaran anggota, proses penginputan data calon anggota, proses pengunjung, proses peminjaman dan pengembalian buku, proses penginputan data buku dan catalog buku pada perpustakaan SMK Negeri 1 Gelumbang masih belum menerapkan sistem informasi karena pada perpustakaan ini masih secara konvensional pada buku besar. Dengan menarapkan sistem informasi ini diharapkan para pengunjung dan pembaca tidak ada kendala lagi.

Berdasarkan latar belakang masalah diatas maka penulis tertarik mengimplementasi metode $U C D$ (User Centered Design) pada rancang bangun sistem informasi perpustakaan (studi kasus : SMK Negeri 1 Gelumbang).

\section{Metode Penelitian}

metode penelitian dapat diartikan sebagai cara ilmiah untuk mendapatkan data yang valid dengan tujuan dapat ditemukan, dikembangkan dan, dan dibuktikan suatu pengetahuan tertentu sehingga dapat digunakan untuk memahami, memecahkan, dan mengatasi masalah.

\subsection{Teknik Pengumpulan Data}

Metode pengumpulan data adalah cara atau teknik yang dapat digunakan peneliti untuk mengumpulkan data. Adapun metode pengumpulan data yang digunakan dalam penelitian ini yaitu :

a. Wawancara

Wawancara adalah suatu cara pengumpulan data yang digunakan untuk memperoleh informasi langsung dari sumbernya. Pada penelitian ini wawancara dilakukan secara langsung oleh penulis kepada narasumber Ir. Neneng Fajarrahmi sebagai salah satu kepala perpustakaan SMK Negeri 1 Gelumbang.

b. Observasi

Observasi adalah suatu teknik atau cara untuk mengumpulkan data dengan jalan mengamati kegiatan yang sedang berlangsung. Pada penelitian ini observasi dilakukan dengan cara datang langsung ke perpustakaan SMK Negeri 1 Gelumbang.

\section{c. Dokumentasi}

Dokumentasi ditujukan untuk memperoleh data langsung dari tempat penelitian meliputi laporan kegiatan, foto, film, dokumenter, dan data yang relevan dengan penelitian.

d. Studi Pustaka

Studi pustaka adalah pengumpulan data yang dilakukan dengan membaca buku dan referensi lainnya yang berhubungan dengan pembahasan penulis di perpustakaan SMK Negeri 1 Gelumbang.

\subsection{Metode UCD (User Centered Design)}

Menurut Ambrowati yang dikutip dari jurnal Muslim dan Saifu (2018), Metode UCD merupakan metode pengembangan sistem yang meniti beratkan kepada user sebagai pusat pengembangan sistem, tujuan atau sifat-sifat, konteks serta lingkungan sistem semua didasarkan dari pengalaman pengguna.

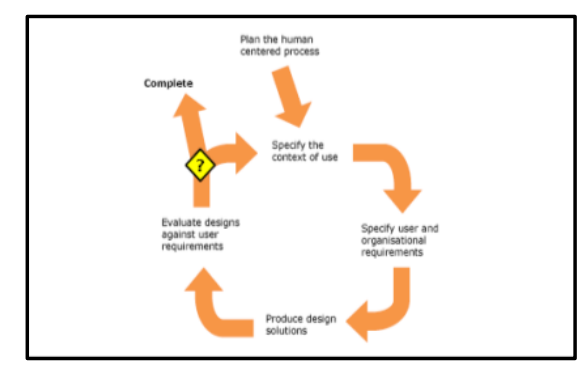

Gambar 1. Proses UCD Berdasarkan ISO 13407:1999 
1. Fokus pada Pengguna

Perancangan harus berhubungan langsung dengan pengguna sesungguhnya atau calon pengguna melalui interview, survey, dan partisipasi dalam workshop perancangan.Tujuannya adalah untuk memahami kognisi, karakter, dan sikap pengguna.

\section{Perancangan Terintegrasi}

Perancangan harus mencakup antarmuka pengguna, sistem bantuan, dukungan teknis seperti perangkat lunak dan perangkat keras yang dibutuhkan serta prosedur untuk instalasi dan pengaturan konfigurasi.

\section{Pengujian Pengguna}

Satu-satunya pendekatan yang sukses dalam perancangan sistem yang berpusat pada pengguna adalah secara empiris dibutuhkan observasi tentang kelakuan pengguna, evaluasi umpan-balik yang cermat, wawasan pemecahan terhadap masalah yang ada, dan motivasi yang kuatuntuk mengubah rancangan.

\section{Perancangan Interaktif}

Sistem yang sedang dikembangkan harus didefinisikan, dirancang, dan ditest berulang kali. Berdasarkan hasil test kelakuan dari fungsi.

\subsection{Proses UCD}

1. Memahami dan menentukan konteks yang akan menggunakan produk, Ini akan menjelaskan untuk apa dan dalam kondisi seperti apa mereka akan menggunakan produk.

2. Menentukan kebutuhan pengguna dan Organisasi, Mengidentifikasi kebutuhan pengguna dan kebutuhan organisasi.

3. Solusi perancangan yang dihasilkan, Membangun desain sebagai solusi dari produk yang sedang dianalisis.

4. Evaluasi perancangan terhadap kebutuhan pengguna, Melakukan evaluasi terhadap desain yang dilakukan apakah tujuan pengguna dan organisasi telah tercapai.

\section{Hasil dan Pembahasan}

\subsection{Tampilan Halaman Login}

Berikut adalah tampilan halaman login admin untuk melakukan proses login ke halaman utama.

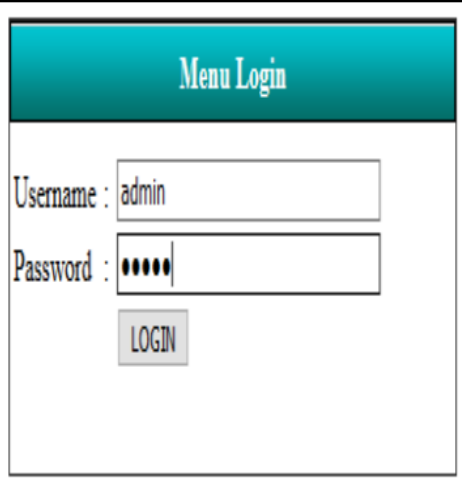

Gambar 2. Halaman Login

\subsection{Tampilan Halaman Beranda}

Berikut adalah tampilan halaman beranda yang merupakan halaman utama dari sistem, dihalaman beranda terdapat menu-menu yang akan dikelola oleh admin.

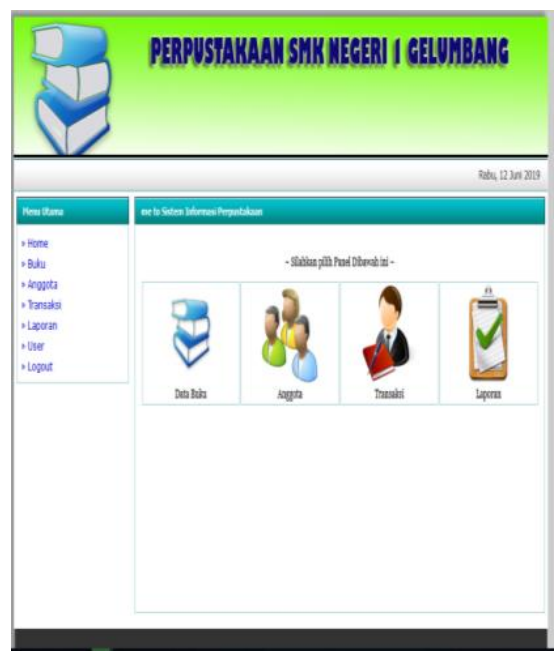

Gambar 3. Halaman Beranda

\subsection{Tampilan Data Buku}

Berikut adalah tampilan halaman data buku yang berisi tentang data buku.

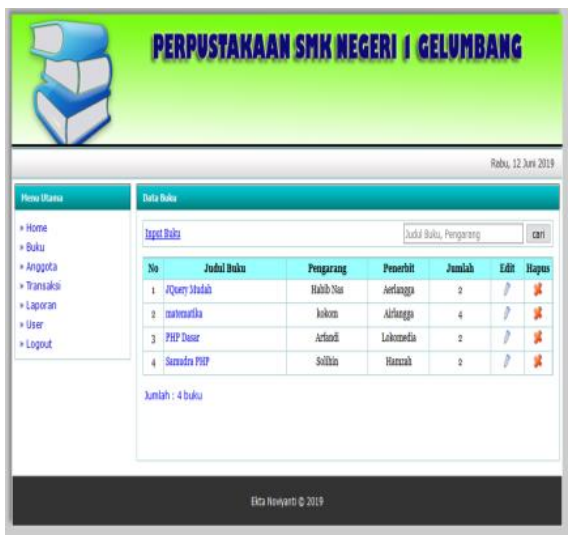

Gambar 4. Data Buku 


\subsection{Tampilan Data Anggota Perpustakaan}

Berikut adalah tampilan halaman anggota perpustakaan.

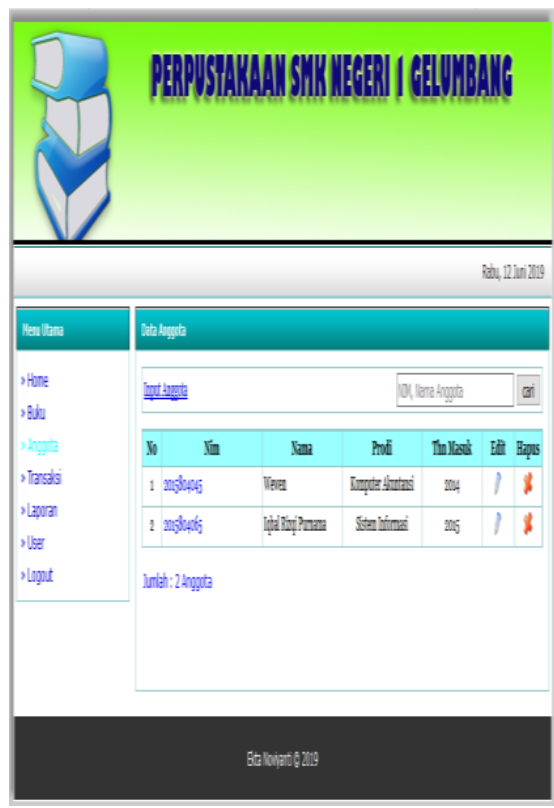

Gambar 5. Data Anggota Perpustakaan

\subsection{Tampilan Halaman Data Transaksi}

Berikut adalah tampilan halaman data transaksi yang berisi tentang informasi data peminjaman, pengembalian, dan perpanjangan waktu pinjam buku.

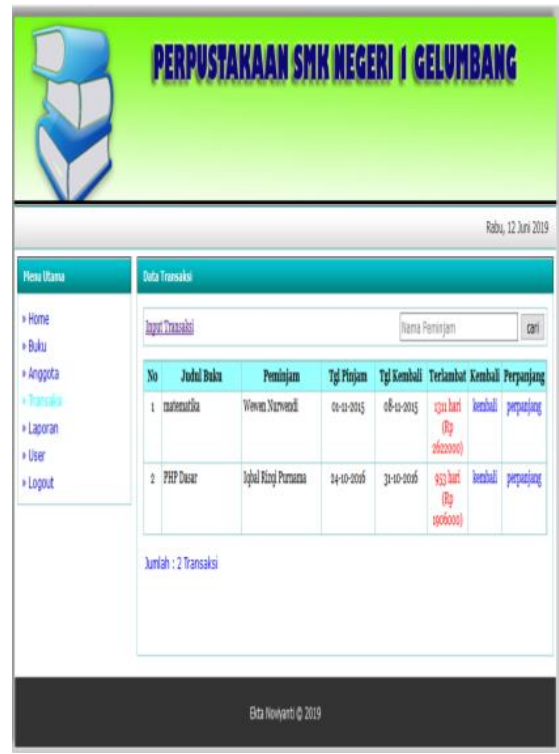

Gambar 6. Data Transaksi

3.6 Tampilan Halaman Laporan

Berikut adalah tampilan halaman data laporan yang berisi tentang informasi data laporan buku,anggota, dan transaki.

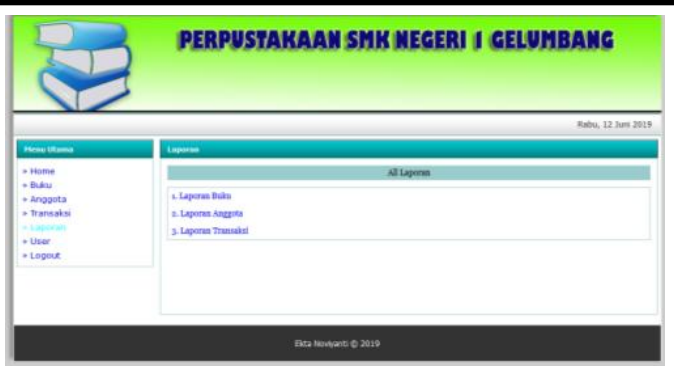

Gambar 7. Data Laporan

3.7 Tampilan Data User

Berikut adalah tampilan data user yang berisi tetang informasi data user atau siswa.

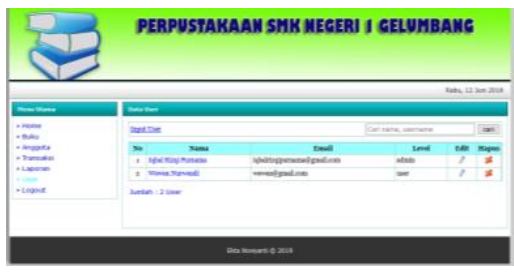

Gambar 8. Data User

\section{Kesimpulan}

Berdasarkan uraian penjelasan dan pembahasan pada penelitian ini dapat ditarik kesimpulan sebagai berikut

a. Membangun Sistem Perpustakaan berbasis web dengan menggunakan bahasa pemrograman PHP.

b. Dengan adanya sistem perpustakaan berbasis web akan mempermudah siswa maupun pengelola perpustakaan dalam hal peminjaman, pengembalian dan membuat laporan.

\section{Ucapan Terimakasih}

Ucapan terima kasih terutama ditujukan kepada kepala SMK NEGERI 1 GELUMBANG yang sudah bersedia menjadi Mitra, dan Terimakasih untuk Sekolah Tinggi Manajemen Informatika Dan Komputer Prabumulih (STMIK Prabumulih) yang telah memberikan support bagi peneliti.

\section{Daftar Rujukan}

[1] A.S. Rosa, M. Shalahudin. Rekayasa Perangkat Lunak Terstruktur dan Berorientasi Objek. Bandung: INFORMATIKA Bandung, 2015.

[2] Abdillah, Willy. 2018. Metode penelitian terpadu sistem Informasi. Yogyakarta : C.V Andi Offset.

[3] Hariadi, Fajar. "Pembuatan Sistem Informasi Perpustakaan pada SDN Sukoharjo Pacitan Berbasis WEB." IJNS, 2013: 48-54.

[4] Indrajani. Database Design. Jakarta: PT Elex Media Komputindo, 2017.

[5] Intan Sandra Yatana Saputri, Mardhiah Fadhli, Ibnu Surya. "Penerapan Metode UCD (User Centered Design) pada ECommerce Putri Intan Shop Berbasis Web." Jurnal Nasiona Teknologi dan Sistem Informasi, 2017: 269-278. 
[6] Lukman Andi Muh. "Pengembangan Sistem Informasi Perustakaan Umum Menggunakan Inslilite 3.0 di Kab. Enerkang." ILKOM Jurnal Ilmiah, 2017: 70-77.

[7] Permana, Aji. "Rancang Bangun Sistem Informasi Berbasis Web (Studi Kasus : Universitas Kuningan)." Jurnal Cloud Information, 2018: 36-40.
[8] Sidik, Betha. Pemograman Web dengan PHP 7. Bandung: Informatika Bandung, 2017.

[9] Sugiyono. 2015. Metode Penelitian Kuantitatif, Kualitatif dan $R \& D$. Alfabeta : Bandung.

[10] Sunyoto Bandung. 2013 . Metode Dan Instrumen Penelitian Ekonomi dan Bisnis. Yogyakarta : CAPS (Center For Academic Publishing Service). 